\title{
Extending Bell's Concept of Interest Convergence: A Framework for Understanding the African American Doctoral Student Experience
}

\author{
Pamela P. Felder \\ University of Pennsylvania, \\ Philadelphia, PA, USA
}

felderpp@gse.upenn.edu

\author{
Marco J. Barker \\ University of North Carolina, \\ Chapel Hill, NC, USA
}

barker@unc.edu

\begin{abstract}
Though rates of doctoral degree completion have increased, African American doctoral students continue to face issues related to race during their doctoral study. Scholars often point to the importance of the faculty and student relationship in doctoral student socialization and success while few explore how race plays a role in the relationship. We concur that the faculty and student relationship is critical to doctoral student persistence and completion. However, given the growing diversity among doctoral students, we contend that it is equally important to consider the ways in which race impacts the doctoral experience. This paper presents qualitative data on the African American doctoral experience and is used to develop an advising framework, emphasizing the role of interest convergence as a feature of culturally receptive advising relationships. Findings indicate instances where students' personal interests or perspectives on the manifestation of race in doctoral education (i.e., personal and professional identity, scholarship, etc.) may be congruent (converge) or incongruent (diverge) with that of a faculty member, advisor, or the departmental or institutional environment. This study addresses how the relational aspects of context and race shape students' perceptions of interactions with faculty and the environment and has implications for advising and creating inclusive institutions.
\end{abstract}

Keywords: doctoral education, doctoral experience, advising, race, diversity

\section{Introduction}

One essential aspect of the doctoral process is the student-faculty relationship, which involves formal and informal advising between faculty members and students and is often cited as the most influential factor of degree completion and success (Lovitts, 2001). Given the significant increase in the number of African Americans obtaining the doctorate (Cook \& Cordova, 2006),

Material published as part of this publication, either on-line or in print, is copyrighted by the Informing Science Institute. Permission to make digital or paper copy of part or all of these works for personal or classroom use is granted without fee provided that the copies are not made or distributed for profit or commercial advantage AND that copies 1) bear this notice in full and 2) give the full citation on the first page. It is permissible to abstract these works so long as credit is given. To copy in all other cases or to republish or to post on a server or to redistribute to lists requires specific permission and payment of a fee. Contact Publisher@InformingScience.org to request redistribution permission. further investigating the role of advising in the African American student experience is warranted. While the number of degrees attained has increased over generations, the representation of African American doctoral degree recipients remains a cause for concern. For example, in 1977, African Americans earned $3.8 \%$ of all doctoral degrees and by 2005 that increased to a mere $5.8 \%$ (Hoffer, Welch, Webber, Williams \& 
Lisek, 2006). For many African American doctoral students, progress towards degree completion involves navigating many barriers.

Previous research about African American ${ }^{1}$ degree attainment has deemed low degree completion rates at preceding educational levels and an under-representation of minority faculty as two primary causes for the slow progression of African American doctoral degree completion rates in the United States (Allen, Haddad, \& Kirkland, 1984; Felder Thompson, 2008; Gasman, Hirschfield, \& Vultaggio, 2008; Willie, Grady, \& Hope, 1991). Within elite institutions, there is a lack of faculty diversity coupled with historical legacies of exclusion that cultivate alienating educational environments (Hurtado, Milem, Clayton-Pederson, \& Allen 1999) In these types of environments, the stakes for developing successful faculty-student advising relationships becomes higher since there are lower levels of African American doctoral student enrollment (Gasman et al., 2008). The disparity of Blacks with doctoral degrees translates into the lack of representation of Black faculty at American colleges and universities.

According to the United States Department of Education National Center of Education statistics report (U.S. Department of Education, National Center for Education Statistics, 2011) on the racial/ethnic composition of college and university faculty, Blacks represent approximately $7 \%$. This same report identified that $19 \%$ of college and university executives, administrators, or managers were Black, Hispanic, Asian/Pacific Islander, or American Indian; minorities account for 33 percent of non-professional staff. To understand the impact of the faculty-student relationship on African American doctoral student success, we focus on advising as a culturally-focused practice by exploring the experiences of African American doctoral students and degree recipients and the ways in which their interests may converge or diverge with their faculty relationships and institutional environment. While there is emerging literature on the diverse aspects of student experiences within doctoral education (Gardner, 2010), our purpose is two-fold: 1) to build upon existing knowledge by expanding discussions about the racial and cultural facets of the doctoral student experience and how faculty mentoring and institutional climate shape doctoral student development towards degree completion; and 2) to recommend practices that facilitate student success.

\section{Literature Review}

\section{Doctoral Advising and Mentoring}

While there has been an increase in advising research, a majority of this work focuses on undergraduate advising (Creamer, 2000; Frank, 2000; McCalla-Wriggins, 2000; Priest \& McPhee, 2000); however, there are stark differences between undergraduate and graduate advising. While undergraduate advising consists of a relationship between students and professional advisors, graduate advising involves a more complex system of students, faculty, departments, and disciplinary communities within and beyond the institution (Kramer, 2000; Lovitts, 2001; Tinto, 1993; Walker, Golde, Jones, Bueschel \& Hutchings, 2008).

Doctoral students work towards benchmarks, where they must continually manage their role as a doctoral student, the expectation of the program, and their relationship with their faculty, depart-

\footnotetext{
${ }^{1}$ Throughout this paper the racial categories of African-American and Black are used interchangeably and largely describe colonized Americans of African descent. These identities are aligned with the following 2010 United States Census Brief racial definition, "Black or African American" refers to a person having origins in any of the Black racial groups of Africa"(Humes, Jones, \& Ramirez, 2011).
} 
ment, peers, and larger national and/or international disciplinary communities (Gardner, 2007, 2008a, 2008b; Gardner \& Barnes, 2007; Golde, 2005; Walker et al., 2008) while undergoing doctoral socialization. Weidman, Twale, and Stein (2001) defined socialization as the two-way, "developmental process" through which a doctoral student acquires a disciplinary identity and understanding of disciplinary practices and norms through "knowledge acquisition, investment [or commitment], and involvement" (p. 11). In this environment, faculty members are the most critical in assisting the student in navigating the doctoral experience and the discipline (Lovitts, 2001). In Chun-Mei, Golde, and McCormick's (2007) study, one student described the studentfaculty advisor relationship as this:

It is impossible to overestimate the significance of the student-advisor relationship. One cannot be too careful about choosing an advisor. This is both a personal and professional relationship that rivals marriage and parenthood in its complexity, variety and ramifications for the rest of one's life. (p. 263)

Similarly, Lovitts (2001) described the advisor as the "central and most powerful person not only on a graduate student's dissertation committee but also during the student's trajectory through graduate school" (p. 131). Although some doctoral education scholars have called for a reengineering of apprenticeship models in graduate education (Walker et al., 2008), the faculty advisor still remains central to the success of doctoral students.

Additionally, researchers call for a greater exploration of the student's cultural perspective of faculty advising and mentorship on graduate student socialization (Gasman et al., 2008; Nettles \& Millett, 2006). This perspective relates to Padilla's Expertise Model (1991) that explores the experiences of successful students of color who attain both theoretical and heuristic knowledge to overcome barriers to success. Padilla's model highlights the value of student experience as an informative resource for learning about student progress as well as the effects of institutional climates and interactions between students and faculty.

\section{The Black Doctoral Student Experience}

The racial climate for Black graduate or doctoral students may be a reflection of the student's interaction with the institution (Clark \& Garza, 1994), department (Davidson \& Foster-Johnson, 2001), and individuals (i.e., faculty and students) (Milner, 2004). According to Nettles (1990), Black doctoral students report a greater sense of racial discrimination than Latino/a and White doctoral students. Robinson (1999) found that doctoral students in predominantly White settings sometimes felt a sense of "social estrangement and socio-cultural alienation" (p. 124).

Further, doctoral students have also reported feeling invisible (Patterson-Stewart, Ritchie, \& Sanders, 1997), isolated (Sligh-DeWalt, 2004), and undervalued (Milner, 2004). These instances lead to Black students feeling as if they must over-perform (Bonilla, Pickron, \& Tatum, 1994; Milner, 2004) or feeling that the quality of their work is less than that of their White peers (Bonilla et al., 1994), thereby creating a sense of academic vulnerability.

Research on African American student persistence has found that prejudice, racism, and discrimination can negatively impact a student's commitment to his or her institution (Sellers, Chavous, \& Cooke, 1998; Shelton \& Sellers, 2000; Steele, 1997; Steele \& Aronson, 1995). This impact negatively affects students' ability to negotiate the environment both academically and socially. Furthermore, these experiences and feelings may also impact the racial and academic identity development of Black doctoral students (Barker, 2012; Felder, 2010) and in other cases lead to racial trauma (Truong \& Museus; 2012).

Doctoral student development, or the transformation whereby graduate students evolve into emerging scholars (Walker et al., 2008), is a process where faculty members can have tremen- 
dous influence to enhance the likelihood of success (Barker, 2011; Felder, 2010; Gasman et al., 2008; Walker et al., 2008). African Americans doctoral students may find it difficult to find the right faculty adviser - one who can mentor their professional development and shape their disciplinary identities during their graduate student socialization experiences (Davidson \& FosterJohnson, 2001; Felder Thompson, 2008; Gasman et al., 2008). Professional identity development at the doctoral level entails the creation of a research agenda and the cultivation of collegial relationships that are important to continued success after degree attainment (Gardner \& Barnes 2007; Lovitts, 2001).

Previous studies of doctoral students may not fully address factors that contribute to the marginalization experience for African Americans as these doctoral students are under pressure to be politically sensitive to the organizational dynamics of their programs (Felder Thompson, 2008; Taylor \& Antony, 2000). Therefore, we explore the experiences of doctoral students at various levels, ranging from enrolled to program completion, with an emphasis on the interaction between the student and her or his advisor, faculty, and environment.

\section{Bell's Concept of Interest Convergence}

Derrick Bell's (1980) early scholarship on interest convergence explains racial relations in the context of legal scholarship and asserts that social justice for people of color occurs when the interests, ideas, and realities of both people of color and Whites converge. While interest convergence is often cited in higher education literature in conjunction with critical race theory as a major tenet of diversity research (Harper, Patton, \& Wooden, 2009), we acknowledge the relational aspects of negotiation, the racial and power dynamics involved in this negotiation, and the building of racial equality awareness.

Our work on doctoral student advising advances Bell's (1980) notion of interest convergence. Hence, interest convergence is presented as an element of the advising process whereby a student's interest converges with the interests held by his or her faculty advisor and is supported by the organizational culture (e.g., institutional mission, departmental climate, and culture). To further illustrate this notion, the quote below characterizes Bell's relationship with his professor, Dr. Wechsler, and suggests that Wechsler's observations were integral in developing a sense of awareness about the impact of the 1954 Brown vs. The Board of Education legislation:

Professor Wechsler warned us early on that there was more to Brown than met the eye. At one point, he observed that the opinion is 'often read with less fidelity by those who praise it than by those by whom it is condemned.' Most of us ignored that observation openly and quietly raised a question about the sincerity of the observer. Criticism, as we in the movement for minority rights have every reason to learn, is a synonym for neither cowardice nor capitulation. It may instead bring awareness, always the first step toward overcoming still another barrier in the struggle for racial equality. (Bell, 1980, p. 533)

In this quote, Bell's thoughts are reflective about Wechsler's influence on his own sense of scholarly inquiry (and his colleagues). These thoughts suggest that Bell is inspired by Wechsler to think critically about the Brown decision. Bell's perceptions represent a critical aspect of the faculty-student advising experience: the process of ideas converging to promote an advancement scholarship. We see this as a natural development in the faculty-student advisement process. Identifying how faculty members and students jointly identify with ideas is essential to understanding the evolution of common interests during the doctoral process.

We argue that this convergence is multi-dimensional and highly subjective to each student-faculty relationship and context and serves as a useful tool for guiding a discussion about African American doctoral student advising. African American doctoral degree completion is highly dependent 
on successful advising or mentoring relationships that serve to support students' scholarly interest and perceptions of organizational support. Two important questions we consider are: How do African American doctoral students' experience and perceive interest convergence during the doctoral process? Considering interest convergence, what are the implications for culturally receptive doctoral advising?

\section{Methodology}

The use of qualitative research allowed us to devise an intentional approach to studying the complexities of situations, experiences, or phenomena. Such qualitative inquiry includes three tenets: the researcher matters, the inquiry into meaning is in service of understanding, and qualitative inquiry embraces new ways of looking at the world (Shank, 2006, p. 10). Since the focus of this exploration is to understand the role of advising within the African American doctoral experience we use a phenomenological approach to explore qualitative data pertaining to student perceptions of environment and faculty. Phenomenology is a strategy of inquiry that identifies the essence of the human condition (Creswell, 2009).

Previous research highlights students' perceptions of academic friends, family, and faculty in building social support networks for doctoral students (Jairam \& Kahl, 2012). Additionally, we contend that environment and race are critical aspects in understanding the African American lived condition within the doctoral process. Therefore, to broaden our understanding of the student experience phenomena, we chose to mix qualitative data allowing us to confirm and crossvalidate student perceptions of environment and race on the advising experience (Creswell \& Plano Clark 2007). We followed Creswell and Plano Clark's exploratory mixed method qualitative analysis procedures to organize data, code themes, identify interrelated categories, and employ peer review for data validation (Creswell \& Plano Clark, 2007).

We want to clarify that our data is only qualitative and analysis procedures are a modified version of the exploratory model that typically represents a combination of qualitative and quantitative data (Creswell \& Plano Clark, 2007). This modification facilitated the creation of a qualitative mixed data set that represents a richer presentation of the phenomena under exploration. After our initial observation data we found that a mixing of qualitative data allowed us to explore student experience within two different environments (the elite institution and the southern institution); serving to legitimate our analysis of data (Creswell \& Plano Clark, 2007). Both types of institutions offer unique historical features of African American educational exclusion where racial tension is prevalent. Elite institutions are known for their history of exclusion and marginalization of the African American student experience. The south is the nation's primary region for commercial slavery and oppression of African Americans.

\section{Study One: Elite Institution}

The first study is a qualitative exploratory case study of eleven African American doctoral degree completers who provided retrospective perspectives of their doctoral experiences. The case study involves in-depth exploration of a program, event, or activity that is bound by time and activity (Creswell, 2009). Thus, perspectives focus on student-faculty relationships and student perceptions of campus climate between 1999 and 2005 from degree completers who have not held their degrees for more than five years. The five-year time frame is consistent with several data reporting guidelines focused on exploring the characteristics of doctoral students. This includes the National Science Foundation's US Doctorates in the $20^{\text {th }}$ Century Special Report (Thurgood, Golladay, \& Hill 2006). Interview responses are retrospective within the scope of completion. Thus, student perceptions are defined to encompass degree completion as a definite result of success, not from a standpoint of potential degree completion. 


\section{Data Collection}

Participants were identified by contacting an alumni office of an elite graduate school and using snowball sampling (Creswell, 2009). Self-selected participants recommended other individuals to interview who might want to share their experiences (Creswell, 2009). Miles and Huberman (1994) recommend snowball sampling in theory-building analysis and mention that it "identifies cases of interest from people who know people who know what cases are information rich" ( $p$. 28). Elite institutions have a tremendous history of excluding African Americans from admission. This legacy is rife with political tension, controversy, and racial conflict (Karabel, 2005). Interview participants who shared perspectives about the environment and racism with peers and colleagues were viewed as expert subjects for this study. Interviews were conducted using a semi-structured interview protocol and focused on commitment to the goal of the institution and completion of the doctoral degree. Participants were asked to identify how environment and faculty contributed to their completion. Each interview was about 60 minutes in length.

\section{Study Two: Southern Institution}

The second study included a qualitative phenomenological method aimed at studying the experiences of Black doctoral students at a predominantly White institution involved in cross-race advising relationships with White faculty. As part of the life-world, there is a natural interaction that takes place between a man or a woman and the world, including surrounding conditions, "impositions," "prohibitions," and other people; the lives of men and women are a series of "episodes" or specific instances that happen in real time, and the individual is consistently orienting himself or herself to the world based on the "life situations" and learned experiences or the "stock of knowledge on hand" (Schutz, 1970, p. 15).

In conducting phenomenology, Patton (2002) noted the importance of research techniques, like "participant observer" and "in-depth interviews" as ways to best understand the culture of those participants. The sample for the second study included 7 Black doctoral students at one research extensive predominantly White institution or PWI in the South (McCormick, 2001). The context of the South is important given the tumultuous history of desegregation, racism, and exclusivity in higher education, particularly Black students' access to southern PWIs (Anderson, 1998, 2003).

Student participants completed at least two years of course work, studied in the social sciences and humanities, identified as Black or African American, had a White faculty advisor, and attended the institution. Compared to students just beginning their program, students who have completed at least half of their coursework are closer to working with faculty along the doctoral education stages of persistence (Lovitts, 2001; Tinto, 1993). Open-ended interviews ranged between 60 to 90 minutes. A standardized open-ended interview protocol was utilized. All participants were asked the same questions in the same order; however, the questions were open-ended and enabled further investigation regarding their "thoughts, beliefs, knowledge, reasoning, motivations, and feelings about" race. The protocol was designed using themes from the literature, theoretical frameworks, and personal experiences and observations.

The final list of participants for both studies is represented in Table 1. 
Table 1. Cross-Study Participants

\begin{tabular}{|l|l|l|l|}
\hline Name & Gender & Status & Study \\
\hline Edward & F & Completed & 1 \\
\hline Tracy & F & Completed & 1 \\
\hline Deanie & F & Completed & 1 \\
\hline Diane & F & Completed & 1 \\
\hline Marlene & F & Completed & 1 \\
\hline Irene & F & Completed & 1 \\
\hline Pierce & M & Completed & 1 \\
\hline Will & M & Completed & 1 \\
\hline Walter & M & Completed & 1 \\
\hline Roy & M & Completed & 1 \\
\hline Parrish & M & Completed & 1 \\
\hline Daphne & F & Completed & 2 \\
\hline James & M & Enrolled & 2 \\
\hline Jordon & F & Enrolled & 2 \\
\hline Lionel & M & Enrolled & 2 \\
\hline Marion & F & Enrolled & 2 \\
\hline Terrie & F & Enrolled & Enrolled \\
\hline Walter & M & & 2 \\
\hline
\end{tabular}

Because the interplay of race, personal interests, and relationships may be reflective of an individual's lived experience in her or his doctoral program, we reexamined both data sets through a phenomenological framework. Phenomenological strategies included identifying significant statements pertaining to interest convergence emerging from the transcribed interviews (Johnson \& Christensen, 2004. Significant statements were those statements that provided "rich detail" and were relevant to the phenomenon (Johnson \& Christensen, 2004 p. 367) - the phenomenon representing interactions that pertained to race and the representation of similar or competing interests. After identifying significant statements, we created a list of meanings associated with significant statements. The third step involved searching for themes among the significant statements and similar and different experiences of the participants. This step included two components: thematic assignment or coding and constant comparison.

Thematic coding included classifying meanings into themes that emerge from a review of the significant meanings for both sets of data (Creswell \& Plano Clark, 2007). Moustakas (1994) detailed phenomenological reduction consisting of bracketing or identifying descriptions related only to the research question and topic, horizonalizing or treating each statement as having "equal value" (p. 97), clustering reduced descriptions into themes, and organizing those themes or clusters into "textual descriptions (p. 97). We reduced data to only those experiences that included experiences where opinions or perspectives were noted to be similar or in competition with those 
of faculty, advisor, or the environment. Moreover, we validated the data by sending the study out for peer-review among scholars who explore the doctoral student experience

To set forth strategies that addressed race as a feature of successful advising, we acknowledged Milner's (2004) framework of researcher racial and cultural positionality, which allowed consideration of our own racial experiences in relation to our participants, their racial positions, and the racial saliency and relevance involved with developing a cultural approach to advising.

\section{Findings}

Throughout their doctoral experience, African American students encountered instances where they felt that their scholarly and personal interests converged, diverged, or needed to be protected in relation to their faculty advisor and their environment (i.e., departmental and institutional culture and climate). In our studies students described various types of experiences where using an interest convergence framework may be useful in understanding the level and intensity of the shared interests between the student and her or his faculty advisor and environment.

We organize the students' experiences into two major categories of interactions: (a) Interactions with Faculty Advisors and Mentors and (b) Interactions with the Environment. These two areas represent two primary types of scenarios described by the students in our studies. Across both studies, findings showed that doctoral students described positive experiences as those experiences where there was a convergence of interests between themselves and faculty and their institutional environment. However, instances where students felt a disconnection between their interests and beliefs with that of a faculty member or the campus environment or climate resulted in students feeling undervalued.

\section{Interactions with Faculty}

Students described varying interactions ranging from faculty advising on academic matters and other faculty discussing cultural or racial issues both related and unrelated to the students' research. These interactions or conversations resulted in interest convergence, divergence, and neutral protection. Neutral protection was instances where there was an intentional effort to not share interests.

The doctoral student participants noted faculty inaccessibility as a barrier to forming a connection or finding shared interests with faculty. Students not having access to faculty negatively impacts doctoral student success (Nettles \& Millett, 2006). Most importantly, Felder (2010) found that having access to faculty is extremely important to Black doctoral students. Though, it's important to note that access to faculty appeared to be perceived differently among students. One student, Tracy, "felt at home" and was able to access and connect to the Black faculty in her department. However, she was only successful in connecting with one or two White faculty members. This connection often related to her advisor connecting her with "people who had similar research interests." Edward, another doctoral student at the private PWI, felt identifying and connecting to faculty was difficult and "was like being in a swamp ... trying to find the dry spots; the dry spots being the supportive faculty." These quotes suggest that when faculty accessibility is low the opportunity for students to find faculty members with whom they can discuss their interests becomes challenging. The inaccessibility of faculty also serves to create "chilly climates" often associated with the African American student experience within predominately White institutions (PWIs) (Hurtado et al., 1999).

Contrastingly, a few of the doctoral students were not interested in having informal conversations or discussing personal interests and insisted in maintaining a level of "professionalism." These doctoral students carried with them the concept of there being a separation of personal self (i.e., 
feelings, background, attitudes, perceptions on life, etc.) and professional self (i.e., academics, university life, dissertation, etc.) that resulted in not being very open with their faculty advisors.

Students carried notions of protecting some interests for the sake of survival. According to Barker (2012), Black doctoral students develop mechanisms and techniques to cope with and navigate their own Black identity in White spaces. As it pertains to Bell's (1980) discussion of interest convergence it is difficult to achieve given the historical significance of race and the possibility of students feeling that racial climates within doctoral programs are not supportive. In developing a culturally receptive approach to advising, faculty must consider how African American students negotiate the historical significance of exclusionary institutional climates and how they serve to shape student perspectives about faculty-student interactions.

Coursework and research present opportunities for some students and faculty to find common interests. This traditional notion of critiquing scholarship connects to Bell's (1980) original position of interest convergence, but again, may be applied loosely as the process of finding and exploring common interests and the outcomes associated with these levels of inquiry. Several doctoral students mentioned that they gained insight into their advisor's perceptions and understandings of race through discussing research. Terrie, at the public PWI, provided an example of discussing with her advisor the role and implications of race emerging from her study.

In Terrie's and other students' cases, the dissertation topic of the doctoral student differed from the research of the faculty advisor. In these cases, the faculty advisor would ask questions about the student's topic or a specific concept. Lionel, whose study included critical race theory, gave an example of how his professor engaged in learning more:

He's asked me about it and I've explained it to him and he's talked to other professors about it and he thinks it's very interesting.

Lionel continued, stating how understanding his professor was about the fact that while race was not his central research area, his professor was willing to learn more and to help Lionel complete the research. Interest convergence ensues when a faculty member is generally interested in supporting a student's work despite a lack of centrality regarding topic. Those students who were studying race felt that their faculty member either had an understanding of the research and was willing to learn more about the topic and frequently asked questions or was able to direct them to others who could add to their research. Students felt a strong sense of support when their faculty showed an interest in the student's own scholarly interest, signifying movement of convergence toward a shared interest. Although there were racial connections or learning moments between faculty and students, there were other academic moments where students felt that their faculty advisor was not racially inclusive. Marion felt a sense of being undervalued in her advisor's classroom. She said,

Well, I've always known that I've always been, you know, in the minority...a minority student in a larger population of majority people. I knew that I would be judged by my race. I knew I could partially be judged by the way I speak. I knew that no matter how smart I am or what degree I'm going for that some people will always be judged as being not as good or not as smart. I think that came across in one of my classes where we all were doctoral students, but it was very clear by some of the other students in the class that my input or any other African American doc student's input wasn't valued as much as the other students.

A doctoral degree completer, Parrish, discusses how a faculty member's insensitivity to his research topic is undervalued,

I think a whole lot of faculty didn't take my work very seriously or even knew what I was doing. I had one faculty member pull me aside and sort of whispered 
to me in her office, "I just want you to know that hip hop is not going to be around forever, so you better make sure you do something other than hip hop" as if all I did all day was like write down rap lyrics, you know what I mean. As if my work was devoid of any sort of intellectual merit or rigor. She was actually trying to look out for me.

In this example, the doctoral student felt a divergence between her research interests, as a Black doctoral student, and those of her advisor. As referenced in her statement, this divergence of interest leaves her feeling devalued by both her faculty advisors. This reaction suggests that negative student satisfaction outcomes may arise when there is a lack of interest convergence.

\section{Interactions with the Environment}

An institution's or department's practices of and commitment to diversity can have a positive impact on the experiences of African American doctoral students (Davidson \& Foster-Johnson, 2001; Gasman et al., 2008). The African American doctoral students in our studies also described the level of divergence between departmental and institutional policy, culture, and climate and the commitment to supporting diversity in general and doctoral students of color in particular. Within this theme, students referred to organizational behaviors or decision-making that diverged from the notion of diversity.

Particularly related to departmental practices, students felt that race played a role in departmental decisions. Lionel shared his feelings of marginalization occurring with his advisor assignment process. Lionel commented that he had feelings that he was chosen because he was a Black male and there was a sense that his advisor's "initial interest" was due to feeling that "these Black [students] are going need more help and support." However, he felt that toward the end of his experience, his advisor's perspective had changed:

He was probably really impressed. I think that [was] his initial [feeling] ...being impressed. Okay, these Black [students] are more capable than what I expected. And I hope that he decided that I'm not just capable for an African American, but I'm capable as a student, period.

Existing literature points to studies where Black doctoral students may feel undervalued through departmental or classroom practices (Bonilla et al., 1994). Jordon felt that departmental racism was practiced through the ease in which White students finished the program compared to her. Jordon struggled to understand how working White students with families were moved through the program at faster rates than Black doctoral students who were full-time. She shared this sentiment:

I didn't work. I devoted full-time to my academics. So, I still haven't graduated. But you have some White students who, for example, I just found out that one student is graduating [soon]. The student started the same semester I started. She's part-time, out-of-state, and carries a full-time job. That just don't even make sense, but with them, they can say, "I'm getting married," or "I'm pregnant," and you know, "We need money." So when they [come] up with their life excuses or reasons, then, they get pushed through the program; whereas for us, it doesn't. We can't just say, “I have this issue. I need to graduate.” It doesn't work like that. We have to still, you know, prove ourselves and almost be two times better to get out the program.

The racial climate for Black doctoral students may be a reflection of the interaction between the student and institution (Clark \& Garza, 1994). The students across both studies highlighted how departmental norms or practices may not appear racially discriminatory but may have some ad- 
verse impact on student success. This includes daily interactions that are slight verbal and behavioral indignities characterized in the literature as micro-aggressions (Sue, Capodilup, \& Holder, 2008; Wang, Leu \& Shoda, 2011; Wing, 2010). Additionally, these practices represented a divergence between departmental mission and goals and African American doctoral students' perceptions of support. Bell (1980) suggested that scholars must continually ask critical questions about practices that facilitate inequality and identify remedies to improve educational practice.

Other students described how the institutional environment influences student persistence. This negotiation is largely political and requires skill:

You could never prove it that it was hostile in court. You would have a very difficult time proving that it was hostile in court. There is no tangible evidence but it's the body language of people, the lack of acknowledgement of your existence, the lack of willingness to really listen to you ... thoughts ... one's thoughts ... the condescending conversations that you could be involved in I think all of that ... and just the way that people sort the ... you know the way ... it's almost as if people just see right through you ... it made me feel ... well there were a range of feelings. First there might be hurt, then there would just be anger and now there is really a feeling of indifference. But ...yeah I just think there is another way to put it ... it is a psychologically toxic environment. (Pierce, private PWI)

Racist experiences with other faculty were more referenced than experiences with students, potentially creating a racial trauma condition (Truong \& Museus, 2012). Walter and Marion, both at the public PWI, worked with faculty who underestimated them. Walter shared a story about completing an essay and having faculty members shocked by how well he articulated his arguments. After seeing that he was an exceptional, academically astute student, Walter felt that the faculty members then came to show him greater respect, wanting Walter to work with them. Marion had an experience where she was mistaken for a master's-level student at one instance and later received a B grade in the faculty member's class, wondering if race was at the center of both experiences: "So anytime something like that comes up, it always crosses your mind like, 'You grade me harder because you feel I'm not supposed to be here,' that kind of thing." Diane, a private PWI student, believed that African American doctoral students were underestimated through the type of advising given to African American students, where faculty did not provide distinctions between program options:

But I think [name of university] should be clear with students about the different degree options. There was some tension in our department about the difference between the Ed.D. and the Ph.D. One time a student who tried to go over from the Ed.D. to the Ph.D. program who was African American was not successfully able to do that for a variety of reasons. I think there was an undercurrent in our department amongst African American students about that issue. You sometimes have to make tough decisions to ultimately decide on what's best for you because sometimes faculty members have their own agendas and they try to steer students a certain way. You have to assert yourself to a certain degree.

This student experience is consistent with the other participants and literature on student perceptions on the expectations of Black doctoral students (Milner, 2004). During her experience as a doctoral student, Sligh-Dewalt (2004) reflected on her experience of advisors not sharing the same level of information similar to what she knew about her White peers and their experiences with faculty. These types of experiences prove to complicate and impede interest convergence between faculty, departments, and students. 
In order to further describe the complex nature of interest convergence and its manifestation within the institution and among faculty advisors and doctoral students, we developed both a matrix and visual model. The matrix, Table 2, represents the environmental or institutional characteristics and the faculty advisor and student characteristics across various levels of interest convergence. Certain behaviors exhibited within the institution or by an individual may indicate a particular level of interest convergence. For example, an advisor who ensures that her doctoral student of color meets doctoral milestones and advises a dissertation topic studying race but does not discuss cultural resources on campus with her student of color may operate within a moderate level of interest convergence.

Additionally, interest convergence may follow a "building pattern" where higher levels of interest convergence build on lower levels. Diagram 2 represents the relationship between each level of interest convergence and the characteristics of the institutional environment, faculty, and student. Furthermore, the model suggests that while some activities within low levels of interest convergence are important (e.g., completing milestones), there are other ways in which faculty and institutions can build greater connections with students of color resulting in higher levels of interest convergence. Students in this study described instances or experiences that fit within and across the various levels of interest convergence, which speaks to the importance of studying the connection between doctoral advising relationship and culture.

Table 2. Interest Convergence Advising Framework

\begin{tabular}{|c|c|c|c|}
\hline & Low & Moderate & $\begin{array}{c}\text { High } \\
\text { (Culturally Receptive) }\end{array}$ \\
\hline $\begin{array}{l}\text { Environment } \\
\text { (Institution) }\end{array}$ & $\begin{array}{l}\text { Inactive policies to sup- } \\
\text { port diversity and/or ra- } \\
\text { cial awareness; little to } \\
\text { no departmental assess- } \\
\text { ment focused on race; } \\
\text { presence of historical } \\
\text { notions of race and rac- } \\
\text { ism within geographical } \\
\text { or institutional climate }\end{array}$ & $\begin{array}{l}\text { Diversity and racial } \\
\text { awareness policies exist } \\
\text { but are not fully opera- } \\
\text { tionalized due to adminis- } \\
\text { trative/structural challeng- } \\
\text { es; minimum required } \\
\text { racial assessments are } \\
\text { performed but no action is } \\
\text { taken; departments recog- } \\
\text { nize the role of context but } \\
\text { may not realize how con- } \\
\text { text impacts the student's } \\
\text { experience }\end{array}$ & $\begin{array}{l}\text { Diversity and racial awareness } \\
\text { policies are operationalized } \\
\text { and there is stakeholder appre- } \\
\text { ciation; departments perform } \\
\text { quantitative and qualitative } \\
\text { assessments of racial climate } \\
\text { and develop strategies to cre- } \\
\text { ate more supportive environ- } \\
\text { ments OR there are clear sup- } \\
\text { port mechanisms for students } \\
\text { of color; departments are insti- } \\
\text { tutional leaders in diversity } \\
\text { programs and develop pro- } \\
\text { grams that question or critique } \\
\text { the geographical context }\end{array}$ \\
\hline $\begin{array}{c}\text { Advising: } \\
\text { Faculty } \\
\text { Characteristics }\end{array}$ & $\begin{array}{l}\text { Obligatory relationship } \\
\text { may involve approval of } \\
\text { paperwork/formal repre- } \\
\text { sentation as an adherence } \\
\text { to policy }\end{array}$ & $\begin{array}{l}\text { Moves beyond obligation } \\
\text { to involve challenges of fit } \\
\text { regarding research inter- } \\
\text { ests. Race is acknowl- } \\
\text { edged but not fully en- } \\
\text { gaged as an aspect of iden- } \\
\text { tity or research interests } \\
\text { during advising }\end{array}$ & $\begin{array}{l}\text { Faculty member is fully en- } \\
\text { gaged and supportive of stu- } \\
\text { dent research interests. This is } \\
\text { demonstrated through research } \\
\text { collaboration on multiple lev- } \\
\text { els. Racial identity or research } \\
\text { interests are fully supported. }\end{array}$ \\
\hline
\end{tabular}




\begin{tabular}{|c|c|c|c|}
\hline Advising: & $\begin{array}{c}\text { Obligatory relationship } \\
\text { may involve approval of } \\
\text { paperwork/formal repre- } \\
\text { sentation as an adherence } \\
\text { to policy; Advising re- } \\
\text { ceived is not considerate } \\
\text { of racial identity or ra- } \\
\text { cially focused research } \\
\text { interests }\end{array}$ & $\begin{array}{c}\text { There may be a struggle to } \\
\text { find support regarding } \\
\text { racial identity and research } \\
\text { topics involving race. }\end{array}$ & $\begin{array}{c}\text { Students are empowered intel- } \\
\text { lectually. Race and research } \\
\text { interests are "received" as val- } \\
\text { ued contributions within the } \\
\text { intellectual community. }\end{array}$ \\
\hline
\end{tabular}

\section{Diagram 1. Interest Convergence Advising Framework}

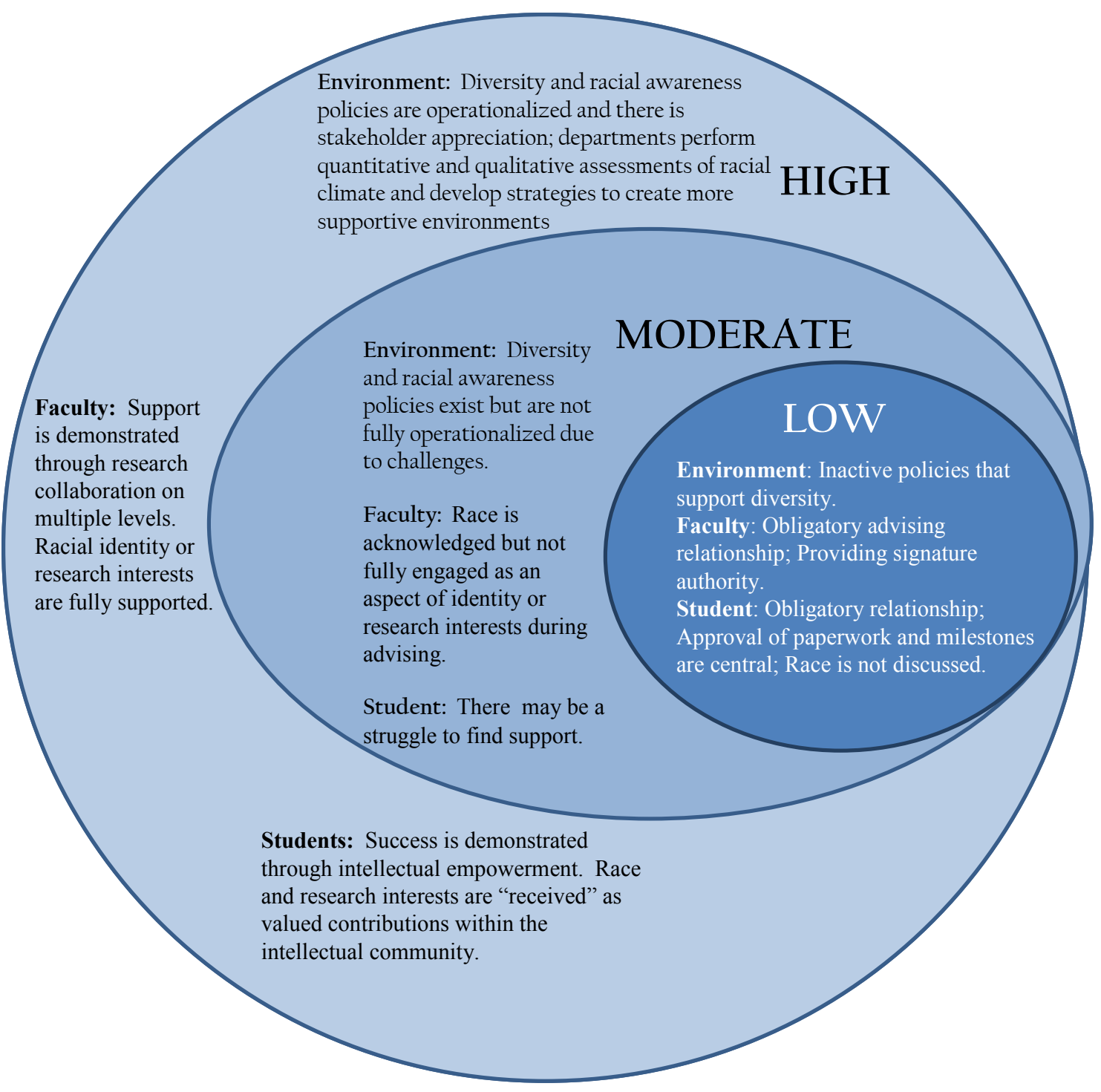




\section{Low Interest Convergence}

Doctoral students are assigned to faculty members based on institutional and programmatic policy. This assignment may be loosely defined at the institutional level and regarded as a mandatory function of the academic process. Advisor assignments may be based on common academic interests. At this stage, a student's research ideas may not be clearly formulated and a specific scholarly interest may not yet be determined. A faculty member's primary activities involve scheduling mandatory meetings as indicated by policy and serving as gatekeeper for facilitating a student's academic experience towards degree completion.

\section{Moderate Interest Convergence}

Similar to the "Low" level, doctoral students are assigned to faculty members based on institutional and/or programmatic policy and this relationship is developed but may be loosely defined. At this level, a student's research ideas may be clearly formulated but may not be directly related to a faculty member's research area. A faculty member's primary activities involve scheduling of mandatory meetings as indicated by policy, serving as gatekeeper for facilitating a student's academic experience towards degree completion. A distinctive feature of this relationship is the faculty member's role as a "point of connection" in directing the student to resources that influence degree completion.

\section{High Interest Convergence}

This level of convergence is depicted in Bell's (1980) experience. It illustrates a direct correlation between a student's interest and the advancement of a mentor's work. In Bell's case, Wechsler served in the capacity of a scholarly mentor rather than an advisor. Wechsler influenced the cultivation of Bell's research that would later facilitate Bell's professional identity development. While still possessing the functional characteristics of the previous levels, this level involves an advancement of thought and reciprocal learning among faculty and student. Other distinctive characteristics of this level include co-teaching, co-publishing, co-grant writing, and co-presenting at conferences. The student-faculty relationship is also cultivated outside of the classroom through social academic activities. While these characteristics may exist at the moderate level, they are often not considered a primary research objective for the student's advancement of research. There may be departmental activities that welcome participation of all students or formal mentoring programs for student of color.

\section{Recommendations for Culturally Receptive Advising}

The environmental and racial themes in our findings can serve to guide advising practices that are culturally receptive towards building interest convergence among faculty and students. While findings are influenced by African American experiences, we believe they can lend guidance for understanding other racial and cultural experiences.

\section{Institutions}

When considering the racial and cultural experiences of doctoral students, institutions should embrace policies that support diversity and racial awareness initiatives. These initiatives can be effective only if they are part of the daily institutional operations and are viewed as priority of stakeholders. These operations should include consistent quantitative and qualitative assessments of racial climate and develop strategies to create more supportive environments. There must be clear agendas for students of color that involve an acknowledgement of the potential impact of environment and race on building advising relationships. A clear purpose for establishing support of students can minimize the social isolation and doctoral student attrition (Ali \& Kohun, 2007). 


\section{Faculty}

The findings demonstrate the unique nature of every student-faculty advising relationship. Interest convergence is more likely to ensue when the faculty member is fully engaged and supportive of his or her students' research interests. African Americans are likely to consider race in their research interests and when they negotiate the academic environment. Faculty members can lend a tremendous amount of support for these students by acknowledging their students' belief systems regarding race within the environment and as it relates to their academic interests. Faculty may also assist students in finding areas of "convergence" within the institution and the discipline. This assistance may include connecting students with cultural-based organizations on campus or with special interest groups within their professional organization.

\section{Students}

African American students are empowered intellectually when their notions about race become a valued aspect of their learning process. Interest convergence is facilitated when racial experiences are understood by other members of the academic community. African American students should critically assess their sense of racial awareness in relation to their contributions to the academic community by way of their presence and research interests. Once students identify supportive advising relationships, it's important for students to clearly articulate with their faculty advisors the ways in which race shapes their research interests.

Interest convergence is a catalyst for facilitating cultural awareness. Culturally receptive advising is a step beyond cultural sensitivity towards a meaningful collaborative practice strategy. Interest convergence serves as a useful tool for guiding a discussion about African American doctoral student advising. African American doctoral degree completion is highly dependent on successful advising or mentoring relationships that serve to support students' scholarly interest. Learning more about how scholarly interests converge during the doctoral process can raise the level of awareness about how faculty advisors can work more effectively with this population.

\section{Limitations}

There are several limitations present in this study. Data collection occurred across two different institutions. Student experience was sometimes guided by the context and may differ based on each institution's unique culture. Additionally, students in these studies pursued doctorates in the humanities and applied social science fields (i.e., business and education) and experiences across other disciplines may very (Becher, 1981). We acknowledge the limitation that different disciplinary cultures may be reflected in different doctoral student experiences.

Areas of future research may include examining advising relationships through a case study approach. Given the unique cultures of departments and the students' responses of how "departments" exhibited behaviors, it may be advantageous to study those departments with reputations of being supportive of Black doctoral students. Future research should also consider other disciplines, particularly those in science, technology, engineering, and mathematics (STEM), where underrepresented groups continue to struggle with degree completion.

\section{Discussion and Conclusions}

Earning the doctoral degree is a daunting and challenging process (Gardner, 2010); however, faculty advisors are in a critical position to assist students in navigating this process (Lovitts, 2001). The African American doctoral students in these studies faced challenges and developed mechanisms for matriculating through or completing their doctoral program. For these students, navigating the doctorate involved negotiating their personal interests with the interests of their faculty advisor and their environment. In some instances, there were interest convergences where the 
students' interests and the interests of others were discussed and moved toward the formation of connections.

In these cases, students felt supported and valued. However, there were other cases where the interests of the students did not align with that of the faculty advisor or with the practices of the department or institution. As a consequence, students did not feel supported and, in some cases, they did not feel valued, which proves to jeopardize doctoral program completion (Milner, 2004). These findings suggest that thinking about advising and the doctoral experience through an interest convergence lens may facilitate conversations on the ways in which interests compete and whose interests are considered, valued, and communicated.

Bell's (1980) concept of interest convergence or reaching common understanding through a learning process is at the core of the doctoral student-faculty advising process. We extend this convergence to represent a multi-dimensional and highly subjective to each student-faculty relationship. However, it can potentially evolve as mandatory formal advising or into a meaningful mentoring. At a minimum, interest convergence is a mandatory relationship shaped by institutional policy that includes a student who is interested in attaining an educational experience and an advisor who is interested in facilitating it. We propose the use of an Interest Convergence Advising Framework (ICAF) (See Table 2) for faculty advisors and students to explore their positionality with their advising relationships. The development of this framework is guided by our conceptual analysis in this paper in addition to our experiences as African American doctoral students and advisors. Furthermore, the phenomena, or essence, of advisement can be highly individualized at the doctoral level. We suggest the use of a cultural receptive advisement tool to identify the essence of the student-faculty relationship to maximize the potential for success and degree completion.

\section{References}

Allen, W. R., Haddad, A., \& Kirkland, M. (1984). Preliminary report: 1982 Graduate professional survey, national study of Black college students. Ann Arbor, MI: The University of Michigan Center for AfroAmerican and African Studies. Unpublished report.

Ali, A., \& Kohun, F. (2007). Dealing with social isolation to minimize doctoral attrition - A four stage framework. International Journal of Doctoral Studies, 2, 33-49. Retrieved from http://www.ijds.org/Volume2/IJDSv2p033-049Ali28.pdf

Anderson, J. D. (1988). The education of Blacks in the south, 1860-1935. Chapel Hill, NC: University of North Carolina Press.

Anderson, J. D. (2003). Race in American higher education: Historical perspectives on current conditions. In W. A. Smith, P. G. Altbach \& K. Lomotey (Eds.), The racial crisis in American higher education: Continuing challenges for the twenty-first century (Rev. ed., pp. 3-22). New York: State University of New York.

Barker, M. (2011). Racial context, currency, and connections: Black doctoral student and white faculty advisor perspectives on cross-race advising. Innovative Education \& Teaching International, 48(4), $387-400$.

Barker, M. (2012). An exploration of racial identity among Black doctoral students involved in cross-race advising relationships. In J. Sullivan (Ed.), African American racial identity: A research exploration across disciplines (pp. 387-413).

Baez, B. (2003). Affirmative action, diversity, and the politics of representation in higher education. The Journal of Higher Education, 74(1), 96-107. 
Baez, B. (2004). Compelling interest: Examining the evidence on racial dynamics in colleges and universities (review). The Review of Higher Education, 27(2), 259-260.

Baez, B. (2006). Leveling the playing field: Justice, politics, and college admissions (review). The Journal of Higher Education, 77(2), 376-378.

Becher, T. (1981). Towards a definition of disciplinary cultures. Studies in Higher Education, 6(2), 109121.

Bell, D. (1980). Brown v. Board of Education and the interest-convergence dilemma. Harvard Law Review, 93(3).

Bonilla, J., Pickron, C., \& Tatum, T. (1994). Peer mentoring among graduate students of color: Expanding the mentoring relationship. New Directions for Teaching \& Learning, 57, 101-113.

Chun-Mei, Z., Golde, C. M., \& McCormick, A. C. (2007). More than a signature: How advisor choice and advisor behaviour affect doctoral student satisfaction. Journal of Further \& Higher Education, 31(3), 263.

Clark, M., \& Garza, H. (1994). Minorities in graduate education: A need to regain lost momentum. In M. J. Justiz, R. Wilson \& L. G. Björk (Eds.), Minorities in higher education (pp. 297-313). Phoenix: American Council on Education and Oryx Press.

Cook, B. J., \& Cordova, D. I. (2006). Minorities in higher education: Twenty-second annual status report. Washington, D.C.: American Council on Education.

Creamer, D. G. (2000). Use of theory in academic advising. In V. Gordon \& W. R. Habley (Eds.), Academic advising: A comprehensive handbook (pp. 18-34). San Francisco, CA: Jossey-Bass Publishers and National Academic Advising Association.

Creswell, J. W. (2009). Research design: Qualitative, quantitative, and mixed methods approaches (3rd ed.). Los Angeles, CA: Sage.

Creswell, J.W. \& Plano Clark, V.L. (2007). Designing and conducting mixed methods research. Thousand Oaks, CA: Sage.

Davidson, M. N., \& Foster-Johnson, L. (2001). Mentoring in the preparation of graduate researchers of color. Review of Educational Research, 71(4), 549-574.

Felder, P. (2010). On doctoral student development: Exploring faculty mentorship and the shaping of African American doctoral student success. The Qualitative Report, 15(2), 455-474.

Felder Thompson, P. (2008). On firm foundations: African American Black college graduates and their doctoral student development in the Ivy League. In M. Gasman \& C. Tudico (Eds.), Historically Black colleges and universities: Triumphs, troubles and taboos (pp. 27-39). New York, NY: Palgrave MacMillan.

Frank, K. S. (2000). Ethnical considerations and obligations. In V. Gordon \& W. R. Habley (Eds.), Academic advising: A comprehensive handbook (pp. 44-57). San Francisco, CA: Jossey-Bass Publishers and National Academic Advising Association.

Gardner, S. K. (2007). "I heard it through the grapevine": Doctoral student socialization in chemistry and history. Higher Education, 54, 723-740.

Gardner, S. K. (2008a). Fitting the mold of graduate school: A qualitative study of socialization in doctoral education. Innovative Higher Education, 33, 125-138.

Gardner, S. K. (2008b). "What's too much and what's too little?": The process of becoming an independent researcher in doctoral education. Journal of Higher Education, 79(3), 326-350.

Gardner, S. K. (2010). Doctoral student development. In S. K. Gardner \& P. Mendoza (Eds.), On becoming a scholar: Socialization and development in doctoral education (pp. 203-222). Sterling, VA: Stylus Publishing. 
Gardner, S. K., \& Barnes, B. J. (2007). Graduate student involvement: Socialization for the professional role. Journal of College Student Development, 48(4), 369-387.

Gasman, M., Hirschfeld, A., Vultaggio, J. (2008). "Difficult yet rewarding": The experiences of African American graduate students in education at an Ivy League institution. Journal of Diversity in Higher Education, 1(2), 126-138.

Golde, C. M. (2005). The role of the department and discipline in doctoral student attrition: Lessons from four departments. The Journal of Higher Education, 76(6), 669.

Harper, S. R., \& Hurtado, S. (2011). Racial and ethnic diversity in higher education (3rd ed.). Boston, MA: Pearson Learning Solutions.

Harper, S. R., Patton, L. D., \& Wooden, O. S. (2009). Access and equity for African American students in higher education: A critical race historical analysis of policy efforts. The Journal of Higher Education, 80(4), 389-414.

Hoffer, T. B., Welch, V., Jr., Webber, K., Williams, K., Lisek, B., \& Hess, M. (2006). Doctorate recipients from United States universities: Summary report 2005. Chicago, IL: National Opinion Research Center.

Humes, K.R., Jones, N.A., \& Ramirez, R.R. (2011). Overview of race and Hispanic origin. 2010 Census Brief Report, C2010BR-02.

Hurtado, S., Milem, J., Clayton-Pederson, A., \& Allen, W. (1999). Enacting diverse learning environments: Improving the climate for racial/ethnic diversity in higher education. ASHE-ERIC Higher Education Report, 26(8). Washington, D.C.: The George Washington University, Graduate School of Education and Human Development.

Jairam, D., \& Kahl, D. H. (2012). Navigating the doctoral experience: The roles of social support in successful degree completion. International Journal of Doctoral Studies, 7, 311-329. Retrieved from http://ijds.org/Volume7/IJDSv7p311-329Jairam0369.pdf

Johnson, B., \& Christensen, L. (2004). Educational research: Quantitative, qualitative and mixed approaches (2nd ed.). Boston: Allyn \& Bacon.

Karabel, J. (2005). The chosen: The hidden history of admissions and exclusion at Harvard, Yale and Princeton. New York: Houghton Mifflin.

Kramer, G. L. (2000). Advising students at different education levels. In V. Gordon \& W. R. Habley (Eds.), Academic advising: A comprehensive handbook (pp. 84-104). San Francisco, CA: Jossey-Bass Publishers and National Academic Advising Association.

Lovitts, B. E. (2001). Leaving the ivory tower: The causes and consequences of departure from doctoral study. Lanham, MD: Rowman \& Littlefield Publishers.

McCalla-Wriggins, B. (2000). Integrating academic advising and career and life planning. In V. Gordon \& W. R. Habley (Eds.), Academic advising: A comprehensive handbook (pp. 162-176). San Francisco, CA: Jossey-Bass Publishers and National Academic Advising Association.

McCormick, A. C. (2001). The Carnegie classification of institutions of higher education. Menlo Park, CA: The Carnegie Foundation for the Advancement of Teaching.

Miles, M., \& Huberman, A. M. (1994). Qualitative data analysis: A sourcebook of new methods. Beverly Hills, CA: Sage Publications.

Milner, H. R. (2004). African American graduate students' experiences: A critical analysis of recent research. In D. Cleveland (Ed.), A long way to go: Conversations about race by African American faculty and graduate students (pp. 19-31). New York: Peter Lang Publishing, Inc.

Moustakas, C. E. (1994). Phenomenological research methods. Thousands Oak, CA: SAGE Publications.

Nettles, M. T. (1990). Success in doctoral programs: Experiences of minority and White students. American Journal of Education, 98(4), 494-522. 
Nettles, M. T., \& Millett, C. M. (2006). Three magic letters: Getting to the ph.D. Batlimore, MD: Johns Hopkins University Press.

Padilla, R. V. (1991). Assessing heuristic knowledge to enhance college students' success. In G. D. Keller, J. R. Deneen, \& R. J. Magillan (Eds.), Assessment and access: Hispanics in higher education, (pp. 81-92). Albany, NY: State University of New York Press.

Patterson-Stewart, K. E., Ritchie, M. H., \& Sanders, E. T. W. (1997). Interpersonal dynamics of African American persistence in doctoral programs at predominantly White universities. Journal of College Student Development, 38(5), 489-498.

Patton, M. Q. (2002). Qualitative research and evaluation methods. Thousands Oaks, CA: Sage.

Priest, R., \& McPhee, S. A. (2000). Advising multicultural students: The reality of diversity. In V. Gordon \& W. R. Habley (Eds.), Academic advising: A comprehensive handbook (pp. 105-117). San Francisco, CA: Jossey-Bass Publishers and National Academic Advising Association.

Robinson, C. (1999). Developing a mentoring program: A graduate student's reflection of change. Peabody Journal of Education, 74(2), 119-134.

Schutz, A. (1970). Alfred Schutz on phenomenology and social relations. Chicago: University of Chicago Press.

Sellers, R. M., Chavous, T. M., \& Cooke, D. Y. (1998). Racial ideology and racial centrality as predictors of African American college students' academic performance. Journal of Black Psychology, 24(1), 827.

Shelton, J. N., \& Sellers, R. M. (2000). Situational stability and variability in African American racial identity. Journal of Black Psychology, 26 (1), 27-50.

Shank, G. D. (2006). Qualitative research: A personal skills approach (2nd ed.). Columbus, OH: Pearson Publishing.

Sligh-DeWalt, C. (2004). In the midst of a maze: A need for mentoring. In D. Cleveland (Ed.), A long way to go: Conversations about race by African American faculty and graduate students (pp. 41-46). New York: Peter Lang Publishing.

Steele, C. M. (1997). A threat in the air: How stereotypes shape intellectual identity and performance. American Psychologist, 52, 613-629.

Steele, C. M., \& Aronson, J. (1995). Stereotype threat and the intellectual test performance of African Americans. Journal of Personality and Social Psychology, 69, 797-811.

Sue, D. W. (2010). Microaggressions in everyday life: Race, gender, and sexual orientation. New Jersey: John Wiley \& Sons Inc

Sue, D., Capodilupo, C. M., \& Holder, A. M. B. (2008). Racial microaggressions in the life experience of black Americans. Professional Psychology: Research and Practice, 39, 329-336.

Taylor, E., \& Antony, J. S. (2000). Stereotype threat reduction and wise schooling: Towards the successful socialization of African American doctoral students in education. The Journal of Negro Education, 69(3), 184-198.

Tinto, V. (1993). Leaving college: Rethinking the causes and cures of student attrition (2nd ed.). Chicago: University of Chicago Press.

Thurgood, L., Golladay, M. J., \& Hill, S. T. (2006). U.S. doctorates in the 20th Century. Arlington, VA: National Science Foundation, Division of Science Resources Statistics, NSF 06-319.

Truong, K. A., \& Museus, S. D. (2012). Responding to racism and racial trauma in doctoral study: An inventory for coping and mediating relationships. Harvard Educational Review, 82(2), 226-254.

Walker, G. E., Golde, C. M., Jones, L., Bueschel, A. C., \& Hutchings, P. (2008). The formation of scholars: Rethinking doctoral education for the twenty-first century. San Francisco: The Carnagie Foundation for the Advancement of Teaching. Jossey-Bass Publishing. 
Wang, J., Leu, J., \& Shoda, Y. (2011). When the seemingly innocuous "stings": Racial microaggressions and their emotional consequences. Personality and Social Psychology Bulletin, 37(12), 1666-1678.

Weidman, J. C., Twale, D. J., \& Stein, E. L. (2001). Socialization of graduate and professional students in higher education: A perilous passage? (Vol. 28). New York: Jossey-Bass.

Willie, C. V., Grady, M. K., \& Hope, R. O. (1991). African-Americans and the doctoral experience: Implications for policy. New York: Teachers College Press.

\section{Biographies}

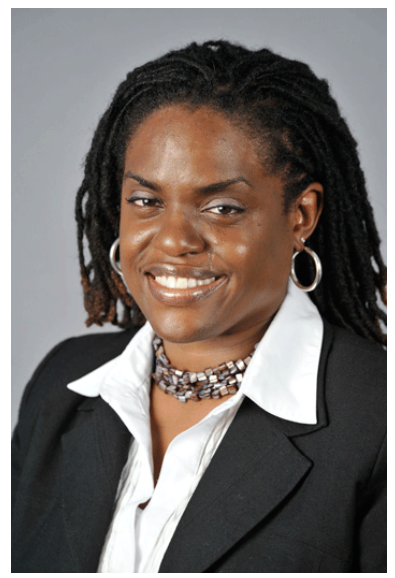

Pamela Felder, Ph.D., University of Pennsylvania. In August 2010 DR. PAMELA FELDER joined the faculty of the Higher Education Program in the Graduate School of Education at the University of Pennsylvania. Her professional background includes a three-year teaching appointment in the Higher and Postsecondary Education Program at Teachers College, Columbia University in New York. Additionally, she served as Lecturer in the Community College Leadership Doctoral Program at Morgan State University in Maryland. She has developed and taught courses in mixed methods research, diversity in higher education, college student retention, professional development in higher education and college student development. Dr. Felder's primary research interests are graduate student development and doctoral degree completion with an emphasis on the impact racial/cultural experiences on persistence. This work includes a focus on academic socialization and the process of disciplinary identity development.

Dr. Felder's research explores the relationship between the belief systems and behaviors of doctoral students and their impact on academic socialization, success, and degree completion. Her work is comprised of an examination of the historical societal factors that have shaped barriers to degree completion and students' approach to negotiating these barriers. Prior socialization experiences serve to shed light on the socialization aspects of students who enter doctoral study and the disciplinary identities of doctoral degree holders as they begin to engage in their professions.

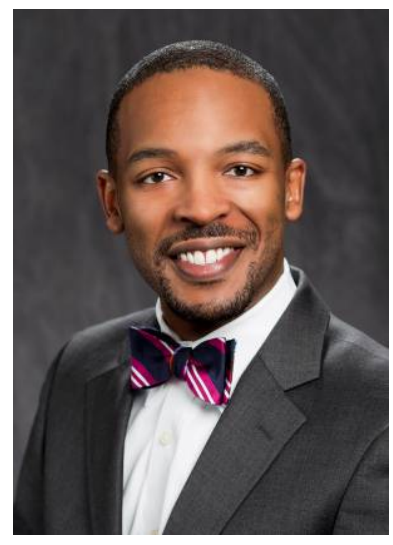

Marco Barker, Ph.D., University of North Carolina at Chapel Hill. DR. MARCO BARKER serves as the Senior Director for Education, Operations, and Initiatives for Diversity and Multicultural Affairs at the University of North Carolina at Chapel Hill. In his capacity, he assists UNC-Chapel Hill's chief diversity officer in daily operations and strategic planning and develops innovative and special initiatives aimed at promoting cultural awareness, facilitating access and success for underserved populations, and increasing institutional diversity.

Dr. Barker earned his undergraduate degree in Industrial Engineering from the University of Arkansas, a MBA from Webster University, and his Ph.D. in Educational Leadership \& Research from Louisiana State University, where he previously served as Director of Educational Equity in the office of Equity, Diversity \& Community Outreach. His research and publications address cross-race mentoring and advising relationships, doctoral education, service-learning, diversity, and leadership in higher education. 